\title{
The residual effect of lambda-cyhalothrin, deltamethrin and dichlorodiphenyltrichloroethane in Zhombe, Kwekwe district, Zimbabwe
}

\author{
N. Lukwa, ${ }^{1}$ A. Makuwaza, ${ }^{1}$ S.L. Mutambu, ${ }^{1}$ P. Munosiyei ${ }^{2}$ \\ ${ }^{1}$ National Institute of Health Research, Causeway, Harare; ${ }^{2}$ Bindura University of Science \\ Education, Zimbabwe
}

\begin{abstract}
Indoor residual house spraying using lambda-cyhalothrin, deltamethrin and dichlorodiphenyltrichloroethane (DDT) was conducted in Zhombe Resettlement area, Zimbabwe. A total of 204/219 (93.1\%), 224/260 (86.2\%) and 257/325 (79.1\%) rooms were sprayed with lambda-cyhalothrin, deltamethrin and DDT wettable powders respectively. Bioassays were conducted on sprayed walls and roofs using 3-5 day old laboratory reared susceptible Anopheles gambiae sensu lato mosquitoes placed in World Health Organization cones.

Bioassays conducted on sprayed walls (1 month), showed that efficacy of lambda-cyhalothrin was the same with DDT but different with deltamethrin and this trend continued in the $2^{\text {nd }}$ month. During the $3^{\text {rd }}$ month, lambda-cyhalothrin killed more mosquitoes than deltamethrin
\end{abstract}

Correspondence: Nzira Lukwa, National Institute of Health Research, P.0. Box CY573, Causeway, Harare, Zimbabwe.

Tel: +263.4.797052 - Fax: +263.4.253979.

E-mail: nziraa33@yahoo.co.uk

Key words: spraying, lambdacyhalothrin, deltamethrin, DDT,

Anopheles gambiae sensu lato.

Contributions: NL, SLM, research concept and design, data collection tools, data analysis and interpretation, manuscript first draft, revision and final approval; AM, PM, improving methodology, data collection tools, data analysis, manuscript revision and final approval.

Acknowledgements: the authors would like to thank Mrs M. Gidi, Mr F Chinyanya, Mr Mupindu and Mrs Rwizi for their support. This study could not have been possible without authority from Dr Chimusoro and Mrs Vimbayi Chikwavaire. Several people assisted in many ways and are duly acknowledged.

Received for publication: 5 June 2012.

Revision received: 25 August 2012.

Accepted for publication: 28 August 2012.

CCopyright N. Lukwa et al., 2012

Licensee PAGEPress, Italy

Journal of Entomological and Acarological Research 2012; 44:e10

doi:10.4081/jear.2012.e10

This article is distributed under the terms of the Creative Commons Attribution Noncommercial License (by-nc 3.0) which permits any noncommercial use, distribution, and reproduction in any medium, provided the original author(s) and source are credited.
$\left(\mathrm{P}=1.931 \times 10^{-14}\right)$, DDT killed more mosquitoes than deltamethrin $(\mathrm{P}=0.0001)$ and lambda-cyhalothrin killed more mosquitoes than DDT (walls). Efficacy of lambda-cyhalothrin and DDT was the same 4 months post spray $(\mathrm{P}=0.487)$, notable differences were seen in lambdacyhalothrin and deltamethrin $\left(\mathrm{P}=2.57 \times 10^{-6}\right)$, DDT and deltamethrin $\left(\mathrm{P}=2.17 \times 10^{-8}\right)$. Efficacy of lambda-cyhalothrin and DDT was the same 5 months post spray $(\mathrm{P}=0.244)$, major differences were found in lambdacyhalothrin and deltamethrin $(\mathrm{P}=0.000)$, DDT and deltamethrin $\left(\mathrm{P}=5.18 \times 10^{-5}\right)$ and this trend continued in the $6^{\text {th }}$ month. One month after spraying roofs, mortality of mosquitoes due to lambdacyhalothrin/deltamethrin $\left(\mathrm{P}=2.56 \times 10^{-5}\right)$, lambda-cyhalothrin/DDT $\left(\mathrm{P}=1.2 \times 10^{-7}\right)$ and deltamethrin/DDT $(\mathrm{P}=0.013)$ were significantly different and this continued in the $2^{\text {nd }}$ month. However, 3 months after spraying, mortality due to lambda-cyhalothrin/deltamethrin $\left(\mathrm{P}=1.46 \times 10^{-6}\right)$, lambda-cyhalothrin/DDT $(\mathrm{P}=0.048)$, and deltamethrin/DDT $(\mathrm{P}=0.004)$ were significantly different and this continued in the $4^{\text {th }}$ month. Five months after spraying roofs, mortality due to lambda-cyhalothrin/ deltamethrin $(\mathrm{P}=0.000)$ and deltamethrin/DDT $\left(\mathrm{P}=6.6 \times 10^{-7}\right)$ were significantly different. Six months after spraying, lambdacyhalothrin/deltamethrin ( $\mathrm{P}=0.34)$, lambda-cyhalothrin/DDT $(\mathrm{P}=0.982)$, and deltamethrin/DDT $(\mathrm{P}=0.64)$ were not significantly different. When using exit window traps, no mosquitoes were collected from rooms sprayed with each of the insecticides over a 6-month period. However, 17, 6, 14, 7, 2 and 3 fed An. gambiae sl mosquitoes were collected in the $1^{\text {st }}, 2^{\text {nd }}, 3^{\text {rd }}, 4^{\text {th }}, 5^{\text {th }}$ and $6^{\text {th }}$ month respectively from unsprayed rooms and none of them died after $24 \mathrm{~h}$.

\section{Introduction}

The use of residual insecticides for indoor residual house spraying (IRS) remains an essential component of malaria control in many parts of the world, including Zimbabwe (Eilsele, et al., 2010). Residual insecticides have life spans of 3-6 months for pyrethroids (Raghavendra et al., 2011) and 8 months to 2 years for organo-chlorines (Taylor et al., 1981). IRS targets mosquitoes that are endophillic (indoor resting) that will eventually pick up a lethal dose before they die. In a study conducted in Kenya, IRS reduced mosquito vector density and disease incidence for a period of 6 months (Zhou et al., 2010). Molineaux \& Gramiccia (1980) attributed vector exophily to the failure to interrupt malaria transmission following IRS with the insecticide propoxur in Nigeria. Sharp et al. (2007) observed that the number of Anopheles gambiae sensu stricto mosquitoes was reduced from 25.5 to 1.9 per trap per 100 nights after spraying with a pyrethroid. World Health Organization (WHO, 2006) set the criteria for knock down as $\geq 95 \%$ and $24 \mathrm{~h}$ mortality as $\geq 80 \%$ and a spraying coverage of $>80 \%$ is required in order to interrupt transmission.

The epidemiology and history of malaria control in Zimbabwe is well 
documented by Taylor \& Mutambu (1986). Malaria vector control started in the 1940s and has witnessed the coming and going of such insecticides as dieldrin and benzene hexachloride and the introduction of synthetic pyrethroids such as deltamethrin, alpha-cypermethrin, and lambda-cyhalothrin. IRS remains an essential component of the National Malaria Control Programme (NMCP) in Zimbabwe. Information from previous work indicates that the malaria vectors in Zimbabwe are still susceptible to dichlorodiphenyltrichloroethane (DDT) and pyrethroids (Manokore et al., 2000) although Munhenga et al. (2008) documented resistance to permethrin and DDT of mosquitoes collected from one locality in Gwave, Zimbabwe.

The residual effect of DDT, lambda-cyhalothrin and deltamethrin was monitored in Zhombe resettlement area, Zimbabwe.

\section{Material and methods}

\section{Study area}

Zhombe is one of the malarious areas in Kwekwe district that is not sprayed by the NMCP during its annual spraying cycle. Malaria spraying by the NMCP focuses on the highly burdened districts.

\section{Insecticides}

DDT 75WP is a wettable powder containing 75\% dichloro-diphenyltrichloro-ethylene, Insectokill 10WP contains 10\% lambda-cyhalothrin wettable powder and Deltaguard 5WP contains 5\% deltamethrin wettable powder. Deltamethrin (moderately toxic) has an acute toxicity of lethal dose for $50 \%$ effect $\left(\mathrm{LD}_{50}\right)$ oral, rat. $>5000 \mathrm{mg} / \mathrm{kg}$ and $\mathrm{LD}_{50}$ dermal, rat. $>2000 \mathrm{mg} / \mathrm{kg}$. Lambda-cyhalothrin (moderately toxic) has an acute toxicity of $\mathrm{LD}_{50}$ oral, rat. $144 \mathrm{mg} / \mathrm{kg}$ and $\mathrm{LD}_{50}$ dermal, rat. $696 \mathrm{mg} / \mathrm{kg}$. DDT (moderately to slightly toxic) has an acute toxicity of $\mathrm{LD}_{50}$ oral, rat. $113-800 \mathrm{mg} / \mathrm{kg}$ and $\mathrm{LD}_{50}$ dermal, rat. $2500-3000 \mathrm{mg} / \mathrm{kg}$

Spraying was conducted using an Xpert 8L Hudson sprayer (H.D. Hudson Manufacturing Company, Chicago, IL, USA), pressurised to 55 psi (pounds per square inch). One hut in Zimbabwe constitutes one room only. A total of 204/219 (93.1\%) rooms were sprayed with lambdacyhalothrin at $30 \mathrm{mg} / \mathrm{m}^{2}, 224 / 260(86.2 \%)$ rooms were sprayed with deltamethrin at $25 \mathrm{mg} / \mathrm{m}^{2}, 257 / 325$ (79.1\%) rooms were sprayed with DDT at $2 \mathrm{mg} / \mathrm{m}^{2}$ and 205 rooms served as the control. All insecticides were sprayed in March 2010.

\section{Mosquitoes}

Anopheles gambiae sensu lato mosquito larvae were collected from the study sites through larval scooping. The larvae were placed in larval bowls (rearing dishes) in a simulated field insectary and reared to adult stage by the provision of fish food. The resulting female adults were given $10 \%$ sugar water. The mosquito colony is susceptible to $4 \%$ DDT, $0.05 \%$ deltamethrin, $0.05 \%$ lambda-cyhalothrin, $0.5 \%$ etofenprox, $0.15 \%$ cyfluthrin and $0.75 \%$ permethrin.

\section{Residual effect}

Bioassays were conducted on randomly selected rooms (Table 1) that were sprayed with DDT, lambda-cyhalothrin or deltamethrin in accordance with WHO guidelines (2006). Three WHO cones ( $8.5 \mathrm{~cm}$ in diameter at the base and $5.5 \mathrm{~cm}$ high) were fastened on different positions on the wall and other 3 on the roof. Ten to fifteen An. gambiae sl mosquitoes were aspirated and placed in each WHO cone and exposed for $30 \mathrm{~min}$. Mosquitoes were retrieved using an aspirator, placed in a holding cup before recording knock down rate. These mosquitoes were provided with $10 \%$ sugar solution in a $50 \mathrm{~mL}$ bottle that contained a wick and this was done over a period of 6 months. Mortality was scored after $24 \mathrm{~h}$. By adding up all mosquitoes that died in each cone for each surface and dividing by the number of cones, the mean mortality per month for each insecticide was calculated.

\section{Effect of insecticides on mosquito behaviour}

This was done monthly using Exit Window Traps (EWT) mounted at 1 window opening at each homestead at 5 p.m. Five rooms for each insecticide were used every month for 6 months and this included 5 unsprayed rooms that served as controls. All the other windows and openings were then closed. Mosquito collection was done using an aspirator and placing mosquitoes in a holding cup by 10 a.m. the following day.

\section{Data analysis}

The data analysis was performed with the ANOVA test (analysis of variance) using the $95 \%$ confidence limit. Mortality of mosquitoes at each time pont was analyzed for the 3 insectides.

\section{Results}

Results for bioassays conducted on sprayed walls are shown in Table 2 . No mortality occurred in the 2 control rooms that were used per month, with a total of 12 control rooms over the 6 -month period. The mortality for mosquitoes exposed to walls sprayed with lambda-cyhalothrin (1 month) was the same with DDT but significantly different with deltamethrin. Two months after spraying, mortality for mosquitoes due to lambdacyhalothrin was significantly different with deltamethrin $(\mathrm{P}=0.003)$ and DDT $(\mathrm{P}=0.03)$. During the same period, DDT and deltamethrin were significantly different $\left(\mathrm{P}=1.31 \times 10^{-5}\right)$. During the $3^{\text {rd }}$ month, lambda-

Table 1. Number of rooms used for bioassays.

\begin{tabular}{|c|c|c|c|c|c|c|c|}
\hline \multirow{2}{*}{$\begin{array}{l}\text { Months post } \\
\text { spraying }\end{array}$} & \multicolumn{2}{|c|}{ Lambda-cyhalothrin } & \multicolumn{2}{|c|}{ Deltamethrin } & \multicolumn{2}{|c|}{ DDT } & \multirow{2}{*}{$\begin{array}{c}\text { Contro } \\
\text { Rooms } \\
\text { used }\end{array}$} \\
\hline & $\begin{array}{l}\text { Rooms where } \\
\text { walls were used }\end{array}$ & $\begin{array}{l}\text { Rooms where } \\
\text { roofs were used }\end{array}$ & $\begin{array}{l}\text { Rooms where } \\
\text { walls were used }\end{array}$ & $\begin{array}{l}\text { Rooms where } \\
\text { roofs were used }\end{array}$ & $\begin{array}{l}\text { Rooms where } \\
\text { walls were used }\end{array}$ & $\begin{array}{l}\text { Rooms where } \\
\text { roofs were used }\end{array}$ & \\
\hline 1 & 4 & 4 & 6 & 5 & 6 & 5 & 2 \\
\hline 2 & 7 & 8 & 6 & 4 & 6 & 5 & 2 \\
\hline 3 & 7 & 7 & 8 & 6 & 4 & 4 & 2 \\
\hline 4 & 4 & 6 & 4 & 4 & 4 & 4 & 2 \\
\hline 5 & 5 & 5 & 4 & 4 & 6 & 9 & 2 \\
\hline 6 & 7 & 9 & 6 & 6 & 4 & 1 & 2 \\
\hline
\end{tabular}

DDT, dichlorodiphenyltrichloroethane. 
cyhalothrin killed more mosquitoes than deltamethrin $\left(\mathrm{P}=1.931 \times 10^{-14}\right)$, DDT killed more mosquitoes than deltamethrin $(\mathrm{P}=0.0001)$ and lambdacyhalothrin killed more mosquitoes than DDT (all results were significantly different). Efficacy of lambda-cyhalothrin and DDT was the same 4 months post spray $(\mathrm{P}=0.487)$, notable differences were seen in lambdacyhalothrin and deltamethrin $\left(\mathrm{P}=2.57 \times 10^{-6}\right)$, DDT and deltamethrin $\left(\mathrm{P}=2.17 \times 10^{-8}\right)$. Efficacy of lambda-cyhalothrin and DDT was the same 5 months post spray $(\mathrm{P}=0.244)$, major differences were found in lambdacyhalothrin and deltamethrin $(\mathrm{P}=0.000)$, DDT and deltamethrin $\left(\mathrm{P}=5.18 \times 10^{-5}\right)$. Efficacy of lambda-cyhalothrin and DDT was the same 6 months post spray $(\mathrm{P}=0.427)$, major differences were found in lambdacyhalothrin and deltamethrin $\left(\mathrm{P}=3.7 \times 10^{-7}\right)$, DDT and deltamethrin $\left(\mathrm{P}=1.58 \times 10^{-9}\right)$. No mortality was observed with the control mosquitoes over the 6 -month period.

Results for bioassays conducted on sprayed roofs are shown in Table 3. One month after spraying, the mortality of mosquitoes due to lambda-cyhalothrin/deltamethrin $\left(\mathrm{P}=2.56 \times 10^{-5}\right)$, lambda-cyhalothrin/DDT $\left(\mathrm{P}=1.2 \times 10^{-7}\right)$ and deltamethrin/DDT $(\mathrm{P}=0.013)$ were significantly different. Results for 2 months after spraying, mortality due to lambdacyhalothrin/deltamethrin $\left(\mathrm{P}=3.65 \times 10^{-11}\right)$, lambda-cyhalothrin/DDT $\left(\mathrm{P}=9.18 \times 10^{-12}\right)$, and deltamethrin/DDT $\left(\mathrm{P}=2.26 \times 10^{-5}\right)$ were significantly different. Three months after spraying, mortality due to lambdacyhalothrin/deltamethrin $\left(\mathrm{P}=1.46 \times 10^{-6}\right)$, lambda-cyhalothrin/DDT $(\mathrm{P}=0.048)$, and deltamethrin/DDT $(\mathrm{P}=0.004)$ were significantly different. Four months after spraying, mortality due to lambda-cyhalothrin/ deltamethrin $\left(\mathrm{P}=1.46 \times 10^{-6}\right)$, lambda-cyhalothrin/DDT $(\mathrm{P}=0.048)$, and deltamethrin/DDT $(\mathrm{P}=0.004)$ were significantly different. Five months after spraying, mortality due to lambda-cyhalothrin/deltamethrin $(\mathrm{P}=0.000)$ and deltamethrin/DDT $\left(\mathrm{P}=6.6 \times 10^{-7}\right)$ were significantly different apart from lambda-cyhalothrin/DDT $(\mathrm{P}=0.811)$. Six months after spraying, lambda-cyhalothrin/deltamethrin $(\mathrm{P}=0.34)$, lambdacyhalothrin/ DDT $(\mathrm{P}=0.982)$, and deltamethrin/DDT $(\mathrm{P}=0.64)$ were not significantly different. No mortality was observed with the control mosquitoes over the 6-month period.

\section{Effect of insecticides on mosquito behaviour}

After installing one exit window trap per room for a total of 5 rooms per treatment per month, no mosquitoes were collected from rooms sprayed with insecticides over a 6-month period. However, 17, 6, 14, 7,
2 and 3 fed An. gambiae sl mosquitoes were collected in the $1^{\text {st }}, 2^{\text {nd }}, 3^{\text {rd }}$, $4^{\text {th }}, 5^{\text {th }}$ and $6^{\text {th }}$ month respectively from unsprayed rooms and none of them died after $24 \mathrm{~h}$.

\section{Discussion and conclusions}

Spraying coverage was above $80 \%$ as required by WHO (2006) in lambda-cyhalothrin and deltamethrin sprayed villages although slightly low in DDT sprayed villages. We did not carry out a study on level of product acceptability in the study villages and therefore cannot explain these observed differences.

The number of rooms used for bioassays sometimes differed in some months due to either availability of mosquitoes or presence of the head of a household to give consent. During the first month on sprayed walls, deltamethrin was not as effective as either lambda-cyhalothrin of DDT but this trend was totally different on sprayed roofs over the same period. In the second and third month, the efficacy of these 3 insecticides was totally different on the walls and roofs. During the $4^{\text {th }}$ month, efficacy of lambda-cyhalothrin and DDT on walls was the same but different with deltamethrin but all roofs were totally different over the same period. In the $5^{\text {th }}$ month, efficacy of lambda-cyhalothrin was the same both on the walls and roofs but different with deltamethrin and this trend in the sixth month on walls, however, mortality on the roof was the same. These results were obtained when a susceptible colony of $A n$. gambiae sl mosquitoes was used. Our observations on DDT did not go beyond 6 months and therefore cannot be compared with observations by Taylor et al. (1981). Insecticide manufacturers claim longer residual periods on their products, making it necessary for control programmes to verify such claims. The residual effect of each insecticide formulation largely depends on the quality of the product (for the manufacturer) and the quality of spraying (for control programmes).

Studies on mosquito behaviour have shown that no mosquitoes were collected in huts sprayed with any of the insecticides. These results imply that mosquitoes died after getting in contact with sprayed surfaces and therefore could not exit sprayed houses. Even if the mosquito population in the study villages had exophilic tendencies, they died before leaving the sprayed houses.

In comparison with mosquitoes that were continuously caught from
Table 2. Bioassays conducted on walls.

\begin{tabular}{|c|c|c|c|}
\hline $\begin{array}{l}\text { Months } \\
\text { post } \\
\text { spraying }\end{array}$ & $\begin{array}{l}\text { Lambda- } \\
\text { cyhalothrin }\end{array}$ & Deltamethrin & DDT \\
\hline 1 & $\begin{array}{c}\text { 107/107 (100\%) } \\
\text { Range (100\%) }\end{array}$ & $\begin{array}{l}\text { 151/161 (93.8\%) } \\
\text { Range (88-100\%) }\end{array}$ & $\begin{array}{c}\text { 161/161 (100\%) }{ }^{\mathrm{a}} \\
\text { Range (100\%) }\end{array}$ \\
\hline 2 & $\begin{array}{l}\text { 214/218 (98.2\%)c } \\
\text { Range (90-100\%) }\end{array}$ & $\begin{array}{l}161 / 172(93.6 \%){ }^{\mathrm{d}} \\
\text { Range (87-100\%) }\end{array}$ & $\begin{array}{c}\text { 171/171 (100\%)e } \\
\text { Range (100\%) }\end{array}$ \\
\hline 3 & $\begin{array}{l}199 / 200(99.5 \%)^{\mathrm{f}} \\
\text { Range }(90-100 \%)\end{array}$ & $\begin{array}{l}\text { 203/225 }(90.2 \%)^{g} \\
\text { Range }(87-100 \%)\end{array}$ & $\begin{array}{l}120 / 126(95.2 \%)^{\mathrm{h}} \\
\text { Range }(93-100 \%)\end{array}$ \\
\hline 4 & $\begin{array}{l}\text { 117/120 (97.5\%) } \\
\text { Range (90-100\%) }\end{array}$ & $\begin{array}{l}\text { 105/117 (89.7\%) } \\
\text { Range (86-97\%) }\end{array}$ & $\begin{array}{l}118 / 120(98.3 \%)^{\mathrm{i}} \\
\text { Range }(93-100 \%)\end{array}$ \\
\hline 5 & $\begin{array}{l}\text { 148/153 }(96.7 \%)^{\mathrm{m}} \\
\text { Range (87-100\%) }\end{array}$ & $\begin{array}{l}97 / 107(90.7 \%)^{\mathrm{n}} \\
\text { Range (88-97\%) }\end{array}$ & $\begin{array}{l}\text { 166/174 (95.4\%) } \\
\text { Range }(92-97 \%)\end{array}$ \\
\hline 6 & $\begin{array}{l}\text { 186/211 (88.2\%)p } \\
\text { Range (81-95\%) }\end{array}$ & $\begin{array}{l}\text { 125/163 }(76.7 \%)^{\mathrm{q}} \\
\text { Range (72-88\%) }\end{array}$ & $\begin{array}{l}96 / 107(89.7 \%)^{\mathrm{P}} \\
\text { Range (80-94\%) }\end{array}$ \\
\hline
\end{tabular}

Table 3. Bioassays conducted on roofs.

\begin{tabular}{|c|c|c|c|}
\hline $\begin{array}{l}\text { Months } \\
\text { post } \\
\text { spraying }\end{array}$ & $\begin{array}{l}\text { Lambda- } \\
\text { cyhalothrin }\end{array}$ & Deltamethrin & DDT \\
\hline 1 & $\begin{array}{l}99 / 99(100 \%)^{\mathrm{a}} \\
\text { Range }(100 \%)\end{array}$ & $\begin{array}{l}\text { 130/138 }(94.2 \%)^{\mathrm{b}} \\
\text { Range }(90-100 \%)\end{array}$ & $\begin{array}{c}\text { 132/136 }(97 \%)^{\mathrm{c}} \\
\text { Range }(96-100 \%)\end{array}$ \\
\hline 2 & $\begin{array}{c}223 / 223(100 \%)^{\mathrm{d}} \\
\text { Range }(100 \%)\end{array}$ & $\begin{array}{l}\text { 106/112 (94.6\%) } \\
\text { Range (92-100\%) }\end{array}$ & $\begin{array}{l}\text { 1291/131 }(98.5 \%) \\
\text { Range }(98-100 \%)\end{array}$ \\
\hline 3 & $\begin{array}{l}\text { 200/203 }(98.5 \%)^{g} \\
\text { Range }(90-100 \%)\end{array}$ & $\begin{array}{l}166 / 179(92.7 \%)^{\mathrm{h}} \\
\text { Range }(88-100 \%)\end{array}$ & $\begin{array}{l}\text { 110/114 }(96.5 \%)^{\mathrm{i}} \\
\text { Range }(90-100 \%)\end{array}$ \\
\hline 4 & $\begin{array}{l}170 / 178(95.5 \%)^{\mathrm{j}} \\
\text { Range }(90-100 \%)\end{array}$ & $\begin{array}{l}112 / 124(90.3 \%)^{\mathrm{k}} \\
\text { Range }(88-100 \%)\end{array}$ & $\begin{array}{l}\text { 103/111 }(92.8 \%)^{1} \\
\text { Range }(90-100 \%)\end{array}$ \\
\hline 5 & $\begin{array}{l}\text { 140/151 }(92.7 \%)^{\mathrm{m}} \\
\text { Range }(88-100 \%)\end{array}$ & $\begin{array}{l}112 / 128(87.5 \%)^{\mathrm{n}} \\
\text { Range }(85-90 \%)\end{array}$ & $\begin{array}{l}238 / 256(92.9 \%)^{\mathrm{m}} \\
\text { Range }(90-100 \%)\end{array}$ \\
\hline 6 & $\begin{array}{c}\text { 224/256 (87.5\%)p } \\
\text { Range (81-94\%) }\end{array}$ & $\begin{array}{l}\text { 138/160 (86.3\%)p } \\
\text { Range (74-90\%) }\end{array}$ & $\begin{array}{l}\text { 24/28 (85.7\%)p } \\
\text { Range (84-90\%) }\end{array}$ \\
\hline
\end{tabular}

[page 48]

[Journal of Entomological and Acarological Research 2012; 44:e10]

OPEN 
EWT installed in unsprayed houses, there are indications that these mosquitoes did not die after being in contact with unsprayed houses and there had to leave these houses under natural conditions. It can be assumed that mosquitoes that were in contact with sprayed structures died and therefore could not be collected from EWT and these results are in agreement with observations of Bruce-Chawett (1964). Mosquitoes collected from unsprayed houses were blood fed and did not die, as observed by Sharp et al. (2007).

In conclusion, DDT and lambda-cyhalothrin had residual effects of 6 months as compared with deltamethrin that had a residual effect of 5 months.

\section{References}

BRUCE-CHWATT L.J., 1964 - Changing tides of chemotherapy of malaria. Br. Med. J. 1: 581-586.

EILSELE T.P., LARSEN D., STEKETEE R.W., 2010 - Protective efficacy of interventions for preventing malaria mortality in children in Plasmodium falciparum endemic areas. Int. J. Epidemiol. 39: 88-101.

MANOKORE V., MURAHWA F.C., CHIREBVU E., 2000 - Absence of insecticide resistance in Anopheles gambiae s.l. after four decades of residual house spraying in Gokwe district, Zimbabwe. J. Med. Entomol. 37: 286-288.
MOLINEAUX L., GRAMICCIA G., 1980 - The Garki project. World Health Organization, Geneva.

MUNHENGA G., MASENDU H.T., BROOKE B.D., HUNT R.H., KOEKEMOER L.K., 2008 - Pyrethroid resistance in the major malaria vector Anopheles arabiensis from Gwave, a malaria-endemic area in Zimbabwe. Malaria J. 7: 247.

RAGHAVENDRA K., BARIK T.K., REDDY B.P., SHARMA P., DASH A.P., 2011 - Malaria vector control: from past to future. Parasitol. Res. 108: 757-79.

SHARP B.L., RIDL F.C., GOVENDER D., KUKLINSKI J., KLIENSCHMIDT I., 2007 - Malaria vector control by indoor residual insecticide spraying on the tropical island of Bioko, Equatorial Guinea. Malaria J. 6: 52.

TAYLOR P., CREES M.J., HARGREAVES K., 1981 - Duration of Anopheles arabiensis control in experimental huts sprayed with DDT and Decamethrin. T. Zimbabwe Sci. Assoc. 61: 1-13.

TAYLOR P., MUTAMBU S.L., 1986 - A review of the malaria situation in Zimbabwe with special reference to the period 1972-1981. T. Roy. Soc. Trop. Med. H. 80: 12-19.

WORLD HEALTH ORGANIZATION, 2006 - Guidelines for testing mosquito aldulticides for indoor residual spraying and treatment of mosquito nets. WHO/CDS/WHOPES/GCDPP/2006.3. Available from: http://whqlibdoc.who.int/hq/2006/WHO_CDS_NTD_WHOPES_GCD PP_2006.3_eng.pdf

ZHOU G., GITHEKO A.K., MINAKAWA N., YAN G., 2010 - Communitywide benefits of targeted indoor residual spray for malaria control in the western Kenya highland. Malaria J. 9: 67. 